\title{
Different Forms of Lidocaine Administration During Transrectal Ultrasound Guided Prostate Biopsy: Results of a Randomized Clinical Trial
}

\section{Özgün Araştrma} Research Article

\author{
Transrektal Ultrason Eşliğinde Prostat Biyopsisinde \\ Farklı Lidokain Formlarının Uygulanması: \\ Randomize Kontrollü Klinik Çalışma Sonuçları
}

\author{
Erdem Kısa $\odot$, Osman Raif Karabacak $\odot$
}

\begin{abstract}
Objective: This study aims to compare the spray form of lidocaine (LS), which is a local anesthetic agent, to its other formulations including lidocaine cream (LC) and lidocaine gel (LG) by administering a visual analogue scale (VAS) to obtain post-transrectal ultrasound- guided biopsy (TRUSG-BX) pain scores.

Methods: Patients who presented to our clinic with lower urinary tract symptoms and/or had PSA levels requested for assessment purposes, or had PSA levels exceeding $2.5 \mathrm{ng} / \mathrm{ml}$ and/or suspicious findings in their rectal examination between 2014 May-2015 February were included in the study. The records of 175 patients were randomized to 4 groups. Group 1: Periprostatic nerve block (PPNB) $5 \mathrm{ml}$ lidocaine injection to both neuromuscular bundles), Group 2: PPNB accompanied by $5 g$ 5\% LC applied to the perianal mucosa 5 min before the procedure, Group 3: PPNB accompanied by perianal-intrarectal $5 \mathrm{ml} 2 \%$ LG 10 min before the procedure, Group 4: PPNB accompanied by 5 doses of $L S(10 \mathrm{mg} / 100 \mathrm{ml})$ administered perianally $2 \mathrm{~min}$ before the procedure. The pain felt by the patients after 30 min from the operation was evaluated using a VAS.

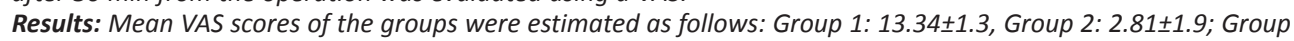

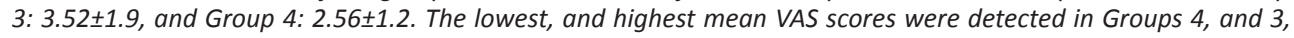
respectively. LS was found to reduce VAS scores statistically significantly more than the other three methods $w$ $(p=0.025<0.05)$.

Conclusion: LS is a noninvasive, safe, and affordable option. Adding LS to PPNB decreases post TRUSG-Bx pain more significantly than the other formulations.
\end{abstract}

Keywords: Prostate cancer, transrectal ultrasound guided biopsy, Local anesthesia, lidocaine

öz

Amaç: Bu çalışmanın amacı, transrektal ultrason (TRUS-bx) eşliğinde prostat biyopsisi öncesi uygulanan lidokainin sprey ile diğer jel ve krem formlarının, TRUS-bx sonrası ortaya çıkan ağrıya olan etkilerini karşılaştırmayı amaçlamaktadır.

Yöntem: 2014 Mayıs-2015 Şubat arasında, PSA düzeyleri 2,5 üstünde olan ve/veya rektal muayenede şüpheli bulgusu olan toplam 175 hasta çalışmaya dahil edildi. Hastalar 4 gruba randomize edildi. Perinöral blokaj (PNB, her iki bölgeye $5 \mathrm{ml}$ lidokain) (Grup 1; $n=40$ ), işlemden 5. $d k$. önce perianal mucosaya $5 \% 5 \mathrm{~g}$ lidokain $\mathrm{krem}(L K)+P N B$ (Grup 2; $n=46)$, işlemden $10 \mathrm{dk}$. önce perianal-intrarektal $5 \mathrm{ml} \% 2$ lidokain jel (LJ) +PNB (Grup 3; $n=50)$, işlemden 2 dk. önce perianal (valsalva manevrasiyla prolabe olan mucosaya) 5 doz lidokain sprey (LS) $(10 \mathrm{mg} / 100 \mathrm{ml})+$ PNB (Grup 4; $n=39$ ) uygulandı. İşlemden $30 \mathrm{dk}$. sonra hastaların duydukları ağrı, vizüel analog skala (VAS) ile değerlendirildi.

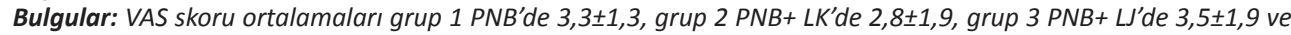
grup $4 P N B+L S^{\prime} d e$ 2,5 1,2 olarak hesaplandı. Ortalama VAS skoru en düşük grup 4, en yüksek grup 3 idi. PNB'ye $L S$ veya LK eklenmesi, VAS ortalamalarını düşürmesine rağmen, LS'nin, diğer 3 yönteme göre ağrı VAS skorunu istatistiksel olarak anlamlı azalttığı gözlemlenmiştir ( $p=0,025<0.05)$.

Sonuç: LS, TRUS-bx öncesi kolay uygulanan, güvenli ve ucuz bir yöntemdir. PNB'ye LS eklenmesi TRUS-bx sonrası ağrı seviyesini diğer yöntemlere göre daha fazla azaltmaktadır.

Anahtar kelimeler: Prostat kanser, transrektal ultrason eşliğinde biyopsi, lokal anestezi, lidokaine

(c) Telif hakkı T.C. Sağılık Bakanlı̆ııı İzmir Tepecik Eğit. ve Araşt. Hastanesi. Logos Tıp Yayıncılık tarafindan yayıılanmaktadır. Bu dergide yayınlanan bütün makaleler Creative Commons Attf-GayriTicari 4.0 Uluslararası Lisansı ile lisanslanmıştır.

(c) Copyright Association of Publication of the T.C. Ministry of Health Izmir Tepecik Education and Research Hospital. This journal published by Logos Medical Publishing.

Licenced by Creative Commons Attribution-NonCommercial 4.0 International (CC BY-NC 4.0) 


\section{INTRODUCTION}

Prostate cancer ( $\mathrm{PCa}$ ) is an important disease with a high incidence and ranks second in cancer-related mortality ${ }^{(1)}$. Transrectal ultrasound- guided biopsy (TRUSG-BX) was first performed by Hodge et al. and it has been the most commonly used method to diagnose PCa to this day ${ }^{(2)}$. In the recent years, biopsies have been obtained from younger patients based on age-specific prostate-specific antigen (PSA) levels and active follow-up has become increasingly common in localized prostate cancers. These factors have highlighted pain control during TRUSG-Bx as an important issue for patient comfort.Pain experienced during TRUSG-Bx is implicated as the primary reason for rejecting repeated biopsies ${ }^{(3)}$.

There exists no standard local or systemic anesthesia method used prior to TRUSG-Bx. Several methods of local anesthesia have been used for pain control in published studies ${ }^{(4-13)}$. For the first time, Nash and colleagues ${ }^{(4)}$ were the first to inject $1 \%$ lidocaine into the neurovascular bundle between the prostate base and the seminal vesicle as a periprostatic nerve block (PPNB). While this method was shown to reduce the pain associated with the extraction of tissue from the prostate, it had no effect on the pain associated with the insertion and maneuvering of the ultrasound probe due to its timing ${ }^{(5,6)}$. Thus, a need has appeared for pre-PPNB application of local anesthetics to ameliorate the pain experienced prior to PPNB, and during the PPNB procedure, as well. Lidocaine, which is a local anesthetic agent, has been applied in different formulations such as gel (LG), cream (LC), and spray (LS) forms, either alone or in combination with PPNB ${ }^{(7-13)}$. Although the analgesic effect of the LG in TRUSG-Bx is disputed in the studies and metanalyses that have been conducted, publications exist that corroborate the notion that LC and LS ameliorate pain ${ }^{(7-15)}$. Particularly, LS was demonstrated to effectively ensure pain control in TRUSGBx (11-13). However, there are no studies in the literature that compare LS to other forms of lidocaine. In this retrospective study, we aimed to compare the spray form of lidocaine, which is a local anesthetic agent, to its other formulations including lidocaine gel and cream by using a visual analogue scale (VAS) to obtain postbiopsy pain scores.

\section{MATERIALS and METHODS}

Following approval from the ethics committee (date $01 / 03 / 2014$ and number 17/38), patients who presented to our clinic with LUTS (lower urinary tract symptoms) and/or had PSA levels requested for assessment purposes, or levels exceeding $2.5 \mathrm{ng} / \mathrm{ml}$ and/or suspicious findings in their rectal examination between 2014 May-2015 February were included in the study. Patients who had priorly experienced allergy to local anesthesia, or had chronic prostatitis, active anal pathologies and underwent anal surgery, and patients who could not tolerate the procedure with local anesthesia were excluded from the study. Patients ( $n=175$ ) who met study criteria were enrolled to the study after obtaining their consent forms. Patients were randomized to 4 groups based on their barcode numbers. The groups were arranged as follows; Group 1: PPNB (5ml lidocaine injected to both neurovascular bundles), Group 2: PPNB accompanied by $5 \mathrm{~g} 5 \%$ LC applied to the perianal mucosa 5 min before the procedure, Group 3: PPNB accompanied by perianal-intrarectal application of $5 \mathrm{ml} \% \mathrm{LG}$ 10 min before the procedure, Group 4: PPNB accompanied by 5 doses of LS $(10 \mathrm{mg} / 100 \mathrm{ml})$ applied perianally (to the mucosa prolapsed with the Valsalva maneuver) 2 min before the procedure.

The patients were administered appropriate antibiotic prophylaxis for TRUSG-Bx based on their rectal swap samples and risk factors ${ }^{(16)}$. In the morning of the operation, a rectal bowel prep was administered 2 hours prior to the operation. A standard 10-12core biopsy was obtained based on prostate size in the standard left lateral decubitus position with a 7.5 $\mathrm{MHz}$ transrectal ultrasonography probe (Aloca Co, Tokyo, Japan). For biopsy, an 18-gauge $20 \mathrm{~cm}$ biopsy needle (Marflow AG, 8134 Adliswil, and Zurich, Switzerland) was used and the material was obtained 
using an automatic gun. The pain felt by the patients after 30 min after the operation was evaluated using a VAS that was scored between 0-10 points. Infectious and bleeding complications encountered in the patients were recorded.

Descriptive statistics was used, and mean $\pm S D$ values were given as numerical variables in the groups, and as number (\%) for the categorical variables. One Way ANOVA test was performed for the statistical analysis using the IBM statistical Package for Social Sciences (SPSS) Version 22.0 program. Results with a $p<0.05$ value were considered statistically significant.

\section{RESULTS}

Group 1 consisted of 40, Group 2, 50, Group 3, 46 patients, and Group 439 patients. Five patients including two patients in Group 1, and one patient each in Groups 2-3-4, were excluded from the study as they could not tolerate the procedure with local anesthesia and their biopsies were obtained under general anesthesia.. The groups were compared in terms of their mean ages, mean PSA values, and mean prostate volumes without any intergroup difference (Table 1). Mean VAS scores of the groups were calculated as 3.3 \pm 1.3 for Group 1 (PPNB), 2.8 \pm 1.9 for Group 2 (PPNB+LC), $3.5 \pm 1.9$ for Group 3 (PPNB+LG), and $2.5 \pm 1.2$ for Group 4 (PPNB+LS). LS was found to reduce VAS scores more than the other three methods with a statistical significant intergroup difference $(p=0.025<0.05)$ (Table 1). Although combining PPNB with $L C$ decreased the mean VAS scores, the difference was not statistically significant.

Table 1. Groups' clinical characteristics and VAS results.

\begin{tabular}{lccccc}
\hline & Group 1 & Group 2 & Group 3 & Group 4 & $\mathbf{p}$ \\
\hline Mean age (years) \pm SD & $63.2 \pm 8.2$ & $64 \pm 6.4$ & $62.4 \pm 8.7$ & $65 \pm 7.9$ & 0.647 \\
Mean PSA (ng ml $\left.{ }^{-1}\right) \pm S D$ & $7.3 \pm 4.7$ & $6.4 \pm 3$ & $5.8 \pm 2.2$ & $7 \pm 3.3$ & 0.354 \\
$\begin{array}{l}\text { Mean prostate volume } \\
\text { (cc) } \pm \text { SD }\end{array}$ & & & & & \\
Mean VAS $\pm S D$ & $3.3 \pm 1.3$ & $2.8 \pm 1.9$ & $3.5 \pm 1.9$ & $2.5 \pm 1.2$ & 0.025 \\
\hline
\end{tabular}

When we further classified patients in the groups as those $\leq 65$, and $>65$ years of age we found that age had no statistical effect on mean VAS scores (Table 2). Similarly, when we classified patients in the groups as those with a prostate volume of $\leq 50 \mathrm{cc}$, and $>50$ cc we determined that only Group 3 patients with prostate volumes of $50 \mathrm{cc}$ or below had statistically lower mean VAS scores (Table 3 ).

Table 2. Groups' pain scores by patient age.

\begin{tabular}{lccc}
\hline & $\leq 65$ year mean VAS \pm SD & $>65$ year mean VAS \pm SD & $\mathbf{p}$ \\
\hline Group 1 & $3.4 \pm 1.4$ & $3.2 \pm 1$ & 0.486 \\
Group 2 & $3 \pm 1.8$ & $2.6 \pm 1.8$ & 0.658 \\
Group 3 & $3.9+1.7$ & $3.2 \pm 2$ & 0.377 \\
Group 4 & $2.4 \pm 1.1$ & $2.9 \pm 1.2$ & 0.468 \\
\hline
\end{tabular}

Table 3. Groups' pain scores by prostate volume.

\begin{tabular}{lccc}
\hline & $\begin{array}{c}\text { 50cc volume mean } \\
\text { VAS } \pm \text { SD }\end{array}$ & $\begin{array}{c}>\text { 50cc volume mean } \\
\text { VAS } \pm \text { SD }\end{array}$ & $\mathbf{p}$ \\
\hline Group 1 & $3.1 \pm 1.3$ & $3.6 \pm 1.1$ & 0.325 \\
Group 2 & $2.1 \pm 1.3$ & $3.4 \pm 2$ & 0.151 \\
Group 3 & $2.9 \pm 1.7$ & $4.1 \pm 1.9$ & 0.013 \\
Group 4 & $2.6 \pm 1.4$ & $2.7 \pm 0.9$ & 0.151 \\
\hline
\end{tabular}

Evaluation of the complications manifested by the patients revealed infectious complications in 15 (8.5\%), hematuria and hematospermia in 52 (29.7\%), and acute urinary retention in $2(1.1 \%)$ patients.

\section{DISCUSSION}

In our study, PPNB and the various application methods of PPNB+lidocaine were compared with regard to pain control during TRUS-Bx. Among local agents, LS $(10 \mathrm{gr} / 100 \mathrm{ml})$ was determined to have a statistically significantly greater effect on the VAS scores estimated 30 minutes after the TRUSG-Bx procedure compared to the other LC and LG forms. Adding the local anesthetic LC to PPNB was not found to have a statistically significant effect although it reduced VAS scores. In this study, the PPNB+LG combination was not found to be superior to PPNB. When we classified patients in the groups as those with a prostate volume below, and above $50 \mathrm{cc}$ we determined that only patients in the LG group with prostate volumes of $50 \mathrm{cc}$ or below had statistically lower VAS scores.

In TRUSG-Bx pain is experienced during the entry of 
the probe into the anal canal, the manipulation of the probe, the application of periprostatic nerve block, and the extraction of the prostate sample using a biopsy needle. Various methods have been used to reduce pain at these stages during TRUSGBx. Among these, PPNB was proven by many studies to reduce pain during TRUSG-Bx and it is the most well-accepted method ${ }^{(4-6)}$. However, applying PPNB comprises one of the most painful components of TRUSG-Bx and it is not possible for PPNB to prevent the pain associated with the entry of the ultrasonic probe, the maneuvering of the probe, and the PPNB procedure on its own due to timing constraints. The pain caused by the entry of the ultrasound probe and its maneuvering during TRUSG-Bx is a somatic pain innervated by the rectal branches of the pudendal nerve. This pain was shown to be more severe than that associated with obtaining TRUSG-Bx after the application of PPNB ${ }^{(17)}$. Therefore, a need arises for local anesthesia, sedoanalgesia, caudal analgesia, and general anesthetics to alleviate the pain that appears at stages preceding the application of PPNB and increase patient comfort.

In the current urology practice, there is no consensus on the method to be used for reducing pain during TRUSG-Bx as well as the method that is most effective. Although local anesthetic agents are preferred more, several methods such as general anesthesia (nitrous oxide), sedoanalgesia (intravenous (i.v.) benzodiazepines) and spinal anesthesia have been tested for pain control ${ }^{(18-20)}$. Furthermore, the agents preferred for pain control during TRUSG-Bx manifest regional differences. While sedoanalgesia is rarely used during TRUSG-Bx in the United Kingdom, a TRUSG-Bx study conducted in Australia and New Zealand in 2013 determined that $57 \%$ of urologists used iv sedation and general anesthesia and $28 \%$ of them used local periprostatic infiltration anesthesia (21). At our clinic, we primarily recommend biopsy under local anesthesia for patients who are to undergo TRUSG-Bx. Patients who cannot tolerate the procedure under local anesthesia or who do not wish to undergo biopsy under local anesthesia are evaluated in coordination with the anesthesia clinic and operated under sedoanalgesia or spinal anesthesia.

Several studies have investigated the administration route of the analgesic agent to be used during TRUSbx. Oral (tramadol, paracetamol), iv routes (tramadol infusion) and local application have been investigated to establish pain control prior to TRUSG-Bx $(4,13,22,23)$. Srudying various meta-analyses on local anesthetics used for pain control during TRUSG-Bx shows that the most commonly used method in current practice is PPNB and intrarectal application of local anesthesia (IRLA) ${ }^{(14,15)}$. IRLA exerts an anesthetic effect as the rectal wall demonstrates perfect drug absorption and the inferolateral nerves of the prostate extend to the rectal wall ${ }^{(7)}$. LG is the most commonly used IRLA in TRUSG-Bx for pain control and it has been associated with conflicting outcomes (15). In 17 randomized controlled studies, $10 \mathrm{ml} 2 \%$ intrarectal LG and non-medicated lubricating gel were compared in most patients. Five of these studies showed that LG was more effective than lubricating gel with a significant change in pain scores. On the other hand, 12 studies determined that LG was statistically ineffective ${ }^{(15)}$. A study conducted by Yung et al. ${ }^{(9)}$ found even higher scores for the LG treatment group regarding pain experienced during TRUSG-Bx. Autorino et al. ${ }^{(24)}$ stated that adding LG to PPNB for pain control was disputable but it was superior to i.v. sedation and general anesthesia in terms of cost and effectiveness. Another IRLA method for pain control during TRUSG-Bx is application of LC. In a study by Skriapas et al. ${ }^{(10)}$ that compared PPNB and LC+PPNB during TRUSG-Bx, adding the local analgesic LC to PPNB was found to be superior in terms of pain control. At our clinic, we hold the view that applying both the gel and the cream formulations of lidocaine prior to PPNB increases comfort for the patient and the doctor.

As a local anesthetic, LS is being used in various areas such as prior to dental surgery, in colonoscopy, nasal endoscopy and insertion of intrauterine devic- 
es for contraceptive purposes ${ }^{(25-27)}$. The first study on the use of LS in urology practice was done by Dell'Atti L. et al. ${ }^{(11)}$ who compared lidocaine/prilocaine cream with LG. VAS scores were evaluated separately for the pain associated with the entry of the ultrasonic probe and the pain experienced during the extraction of prostate material. The group that applied LS (10 gr/100 ml) demonstrated statistically significantIy lower VAS scores at both stages compared to the other two methods. Based on their 5-year experience of using LS (10 gr/100 ml) for analgesia control during TRUSG-Bx Dell'Atti L. et al. ${ }^{(12)}$ stated that $82 \%$ of the patients reported they could undergo TRUSG$\mathrm{Bx}$ again with the same local analgesic. They attributed this to the fact that LS is infiltrative, applied easily, and psychologically well tolerated. Another study conducted with LS by Anastasi G. et al. (13) showed that LS (15\%) was more effective than PPNB on VAS scores obtained at the end of TRUSG-Bx. The same study highlighted that LS (15\%) was statistically superior to the lidocaine+prilocaine combination with regard to VAS scores obtained after $30 \mathrm{~min}$ following biopsy. Our opinion based on this study is that administering LS during TRUSG-Bx is advantageous both for patient comfort and for the doctor as it is administered easily. During the administration of LS, it is particularly important for analgesia to administer LS onto a prolapsed rectal mucosa with the patient straining. LS takes effect 2 minutes after being administered onto the mucosa. Following this effect, probe insertion is comfortable and this leads to reduced pain during PPNB and lower pain scores at the end of biopsy.

The effects of age and prostate volume on the pain experienced during TRUSG-Bx have been investigated in various studies. In the study where Bingquan $\mathrm{L}$. et al. ${ }^{(28)}$ compared PPNB and the intraprostatic local anesthesia method, patients with small prostates ( $\leq$ $48 \mathrm{ml}$ ) and patients above the age of 65 demonstrated lower pain scores. Various studies have shown that patients with large prostates and young patients who experienced rectal complications are predisposed to sustain more pain and these patients are reported to benefit more from combined treatments ${ }^{(29-31)}$. In our study, interestingly, only the patients in the PPNB + LG group with prostate volumes of $50 \mathrm{cc}$ or below demonstrated lower VAS scores.

The primary limitation of our study was the low number of patients in patient groups. The second limitation was the non-equivalent numbers of patients in the randomized groups. The reason for this was that, despite our initial plan to include 39 patients in each group, we continued enrolling patients to the other groups until the number of patients in the LS group reached 39 . The third limitation could be described as the uncertainty regarding the optimal dose of LS for the mucosa and anal sphincter and the selection of the dose based on other studies done with LS ${ }^{(11,12)}$. On the other hand, the strengths of our study include the fact that, although it was based on retrospective data, it was conducted simultaneously with another study in a prospective randomized fashion and that it constitutes the first study that has compared LS to the other formulations of lidocaine and demonstrated its superiority ${ }^{(16)}$.

\section{CONCLUSIONS}

The TRUSG-Bx procedure is being performed at increasing rates due to its use in diagnosing PCa and the increasing use of active follow-up in localized prostate cancers. This has made pain control during biopsy important for patient comfort and life quality. Adding LS to PPNB, which has become a standard method utilized during TRUSG-Bx, decreases postoperative pain more significantly than the other forms. LS is a non-invasive, safe, and affordable option. We recommend this application as the primary method to reduce the pain associated with the TRUSG-Bx procedure as it is comfortable for the patient, easy to administer, and delivers quick analgesia. 
E. Kısa ve O.R. Karabacak, Different Forms of Lidocaine Administration During Transrectal Ultrasound Guided Prostate Biopsy: Results of a Randomized Clinical Trial

Ethics Committee Approval: Received from SBÜ Ankara Diskapi Health Application Research Center NonInterventional Ethics Committee (01.03.2014/17-38).

Conflict of Interest: There is no conflict of interest.

Funding: There is no financial support.

Informed Consent: Was taken.

Etik Kurul Onayı: SBÜ Ankara Diskapi Sağlık Uygulama Araştırma Merkezi Girişimsel Olmayan Etik Kurulundan alınmış$\operatorname{tır}$ (01.03.2014/17-38).

Çıkar Çatışması: Yoktur.

Finansal Destek: Yoktur.

Hasta Onamı: Hasta onamları alınmıştır.

\section{REFERENCES}

1. Siegel RL, Miller KD, Jemal A. Cancer statistics. CA Cancer J Clin. 65:5-29. [CrossRef]

2. Hodge KK, McNeal JE, Terris MK, Stamey TA. Random systematic versus directed ultrasound guided transrectal core biopsies of the prostate. J Urol. 1989;142(1):71-4. [CrossRef]

3. Irani J, Fournier F, Bon D, Gremmo E, Dore B, Aubert J. Patient tolerance of transrectal ultrasound-guided biopsy of the prostate. Br J Urol. 1997;79:608-10. [CrossRef]

4. Nash PA, Bruce JE, Indudhara R, Shinohara K. Transrectal ultrasound guided prostatic nerve blockade eases systematic needle biopsy of the prostate. J Urol. 155(2):607-9. [CrossRef]

5. Soloway MS, Obek C. Periprostatic local anaesthesia before ultrasound guided prostate biopsy. J Urol. 2000;163:172-3. [CrossRef]

6. Pareek G, Armenaskas NA, Fracchia JA. Periprostatic nerve blockade for transrectal ultrasound guided biopsy of the prostate: a randomized, double-blind, placebo controlled study. J Urol. 2001;166:894-7. [CrossRef]

7. Song SH, Kim JK, Song K, Ahn H, Kim CS. Effectiveness of local anaesthesia techniques in patients undergoing transrectal ultrasoundguided prostate biopsy: a prospective randomized study. Int J Urol. 2006;13(6):707-10. [CrossRef]

8. Stirling BN, Shockley KF, Carothers GG, Maatman TJ. Comparison of local anesthesia techniques during transrectal ultrasound-guided biopsies. Urology. 2002;60(1):89-92. [CrossRef]

9. Yung WY, Li ML. A randomized prospective control trial of rectal administration of xylocaine gel and pain tolerance of transrectal ultrasoundguided biopsy of prostate. BJU Int 2012;109:12.

10. Skriapas K, Konstandinidis C, Samarinas M, Kartsaklis $P$, Gekas A. Pain level and anal discomfort during transrectal ultrasound for guided prostate biopsy. Does intrarectal administration of local anesthetic beforeperiprostatic anesthesia makes any difference? Minerva Urol Nefrol. 2009;61:137-42.

11. Dell'Atti L, Daniele C. Lidocaine spray administration during transrectal ultrasound guided prostate biopsy modified the discomfort and pain of the procedure: results of a randomized clinical trial. Arch Ital Urol Androl. 2010;82:125-7.

12. Dell'Atti L. Lidocaine spray administration in transrectal ultrasoundguided prostate biopsy: Five years of experience. Arch Ital Urol Androl. 2014;86(4):340-3. [CrossRef]

13. Anastasi G, Subba E, Pappalardo R, et al. Transrectal ultrasound (TRUS) guided prostate biopsy: Three different types of local anesthesia. Arch Ital Urol Androl. 2016;88(4):308-10.

\section{[CrossRef]}

14. Yan $P$, Wang $X Y$, Huang $W$, Zhang $Y$. Local anesthesia for pain control during transrectal ultrasound-guided prostate biopsy: a systematic review and meta-analysis.J Pain Res. 2016;9:787-96. [CrossRef]

15. Lee $\mathrm{C}$, Woo HH. Current methods of analgesia for transrectal ultrasonography (TRUS)-guided prostate biopsy -- a systematic review. BJU Int. 2014;113(Suppl 2):48-56. [CrossRef]

16. Kisa E, Altug MU, Gurbuz OA, Ozdemir H. Fosfomycin: a good alternative drug for prostate biopsy prophylaxis the results of a prospective, randomized trial with respect to risk factors.Int Braz J Urol. 2017;43(6):1068-74. [CrossRef]

17. Philip J, McCabe JE, Roy SD, Samsudin A, Campbell IM, Javlé P. Site of local anaesthesia in transrectal ultrasonographyguided 12-core prostate biopsy:does it make a difference? BJU Int. 2004;93:1218-20.

18. Masood J, Shah N, Lane T, Andrews H, Simpson P, Barua JM. Nitrous oxide (Entonox) inhalation and tolerance of transrectal ultrasound guided prostate biopsy: a double-blind randomized controlled study. J Urol. 2002;168:116-20. [CrossRef]

19. Turgut AT, Ergun E, Kosar U, Kosar P, Ozcan A. Sedation as an alternative method to lessen patient discomfort due to transrectal ultrasonography-guided prostate biopsy. Eur J Radiol. 2006;57:148-53. [CrossRef]

20. Kucur M, Goktas S, Kaynar M, et al. Selective Low-Dose Spinal Anesthesia for Transrectal Prostate Biopsy: A Prospective and Randomized Study. J Endourol. 2015;29(12):1412-7. [CrossRef]

21. Davis P, Paul E, Grummet J. Current practices of prostate biopsy in Australia and New Zealand - the survey. BJU Int. 2013;111:96.

22. Pendleton J, Costa J, Wludyka P, Carvin DM, Rosser CJ. Combination of oral tramadol, acetaminophen and $1 \%$ lidocaine induced periprostatic nerve block for pain control during transrectal ultrasound guided biopsy of the prostate: a prospective, randomized, controlled trial. J Urol. 2006;176:1372-5. [CrossRef]

23. Obek C, Ozkan B, Tunc B, Can G, Yalcin V, Solok V. Comparison of 3 different methods of anesthesia before transrectal prostate biopsy: a prospective randomized trial. J Urol. 2004;172:502-5. [CrossRef]

24. Autorino R, De Sio M, Di Lorenzo G, et al. How to decrease pain during transrectal ultrasound guided prostate biopsy: a look at the literature. J Urol. 2005;174:2091-7. [CrossRef]

25. DiMarco, Wetmore AO. Clinical comparison: Fast-acting and traditional topical dental anesthetic. Anesth Prog. 2016 Summer;63(2):55-61. [CrossRef]

26. Şahin Mi, Kökoğlu K, Güleç Ş, Ketenci I, Ünlü Y. Premedication methods in nasal endoscopy: A prospective, randomized, double-blindstudy. ClinExpOtorhinolaryngol.2017;10(2):15863. [CrossRef]

27. Torky H, Moussa A, El-Desouky ES, Dief O, Ahmed A. Lidocaine gel vs lidocaine spray in reducing pain during insertion of the intrauterine contraceptive device.Eur J Contracept Reprod Health Care. 2017;22(2):159-61. [CrossRef]

28. Bingqian L, Peihuan L, Yudong W, Jinxing W, Zhiyong W. Intraprostatic local anesthesia with periprostatic nerve block for transrectal ultrasound guided prostate biopsy. J Urol. 2009;182(2):479-83. [CrossRef]

29. Giannarini $G$, Autorino $R$, Valent $F$, et al. Combination of perianalintrarectal lidocaine-prilocaine cream and periprostatic nerve block for pain control during transrectal ultrasound guided prostate biopsy: a randomized, controlled trial. J Urol. 2009;181(2):585-91. [CrossRef]

30. Raber M, Scattoni V, Roscigno M, et al. Topical prilocaine-lidocaine cream combined with peripheral nerve block improves pain control in prostatic biopsy: results from a prospective randomized trial. Eur Urol. 2008;53(5):967-73. [CrossRef]

31. Yucel C, Budak S. Association between large prostate calculi and prostate cancer. Arch Ital Urol Androl. 2018;90(3):181-3. [CrossRef] 